\title{
Gamification as a Mean of Driving Online Consumer Behaviour: SOR Model Perspective
}

\author{
Rimantas Gatautis, Elena Vitkauskaite, Agne Gadeikiene, Zaneta Piligrimiene
}

Kaunas University of Technology

K. Donelaicio st. 73, LT-44029, Kaunas, Lithuania

E-mail.rimantas.gatautis@ktu.lt,elena.vitkauskaite@ktu.edu,agne.gadeikiene@ktu.lt,zaneta.piligrimiene@ktu.lt

cross $^{\text {ref }}$ http://dx.doi.org/10.5755/j01.ee.27.1.13198

Gamification recently attracted attention from practitioners and researchers aiming to gain understanding about gamification applicability. According to forecasts of various market research agencies, application of gamification in activities of companies increases and gamification market growth will continue in the future. As gamification is usually focused on customers, it is naturally related to consumer behaviour. However, there is a lack of studies approaching gamification from consumer behaviour perspective. Because gamification is strongly driven by information technologies, the paper seeks to propose an integrated framework for gamification impact on online consumer behaviour. In order to achieve it, the paper explores origins of gamification concept, compares it to similar concepts, proposes gamification definition and provides an overview of the pyramid of key gamification elements: game components, game mechanics, game dynamics. The further paper analyses different models of online consumer behaviour with emphasis on the application of the stimulus-organism-reaction (SOR) model. SOR model is used for characterising online stimulus (company controlled elements) and their impact on online consumer behaviour. In order to develop the framework, interdependencies of approaches of the pyramid of key gamification elements and SOR model are analysed by identifying factors related to the virtual environment, process, and social dimensions.

Keywords: Game Elements, Game Dynamics, Game Mechanics, Gamification, Online Consumer Behaviour, SOR Model.

\section{Introduction}

According to Gartner (2014) emerging technology hype cycle, gamification left the phase of the peak of inflated expectations and moved towards disillusionment phase. However, gamification gains increasingly more attention from academia and practitioners. Practitioners' attention is mostly driving towards the application of gamification in order to achieve enterprise goals, on the other hand, researchers aim to get a better understanding of this phenomenon itself.

The term of gamification was presumably first used in 2002. However, it was not until 2010 that the concept of gamification gained popularity and received greater interest. It attracted the attention of game creators who aimed to use the game technique in games themselves in order to increase players' engagement. In the same year, the concept received tremendous interest from business representatives. According to Sinanian (2010), this prompted belief in its success in improving consumer relations and in engaging them in activities that are not directly related to games. This belief has been supported by a number of studies reporting a positive effect of gamification (Hamari \& Koivisto, 2015).

In their studies, Hamari and Lehdonvirta (2010), as well as Zichermann and Linder (2010), analysed gamification as a concept of using elements of game design in non-game activities. Consequently, companies started implementing the gamification in their marketing activities, apply it to increasing everyday performance and created platforms of gamification that were meant to increase the efficiency of company's performance. In 2010
Bunchball, the originator of gamification and current leader in the development of services related to gamification was the first organisation to present the solutions of game design usage as a service to other companies. They also launched other organisations, the aim of which was to share the experience and ideas of implementing gamification on internet websites that were not directly related to games.

Taking into the consideration the above-described context, gamification is explicitly addressed as a means to drive consumer behaviour. Though there is a significant number of studies on online consumer behaviour (Chen, Yan, \& Fan, 2015), there is a lack of studies approaching gamification from consumer behaviour perspective (Sigala, 2015). On the other hand, as gamification is heavily driven by information communication technologies (ICT), it is natural to address interrelations of gamification and consumer behaviour online. Therefore, the scientific problem dealt with in the article is defined by the following question: how does gamification impact online consumer behaviour?

Having this is mind, the purpose of the research is to propose an integrated framework for gamification impact on online consumer behaviour.

In order to achieve this purpose, the method of systematic analysis of sources will be employed to explore concepts of gamification and online consumer behaviour, and to define interdependencies between the gamification and online consumer behaviour. 


\section{The Concept of Gamification}

Gamification is a new term that gained popularity and recognition in 2010, although Meloni and Gruener (2012) state that game mechanics and elements, as a certain principle, have long been present in corporate marketing activities. On the other hand, the authors maintain that research into gamification and explanation of working principles started only in 2010. Inquiries into ways to use gamification in non-game activities and into the effect the concept may have on activities of organisations have started.

The term gamification could be misunderstood, by relating it to the use of actual games, real-world simulations, or even game theory (Robson, Plangger, Kietzmann, McCarthy, \& Pitt, 2015). According to Groh (2012), in order to determine the place of gamification concept in the context of concepts related to games, it is important to understand the difference between two poles of game activity, namely, playing and gaming. While explaining the difference between those two poles, Caillois and Barash (2001) claim that playing (Greek $\pi \alpha l \delta l \alpha ́$ (paidia)) defines free-form, expressive, improvised behaviour and meanings. Whereas, gaming (Latin ludus) is characterised by rule-bound and goal-driven game. Groh (2012), with reference to Alfrink (2011), states that gamification is exclusively related to ludus and has little to do with paidia.

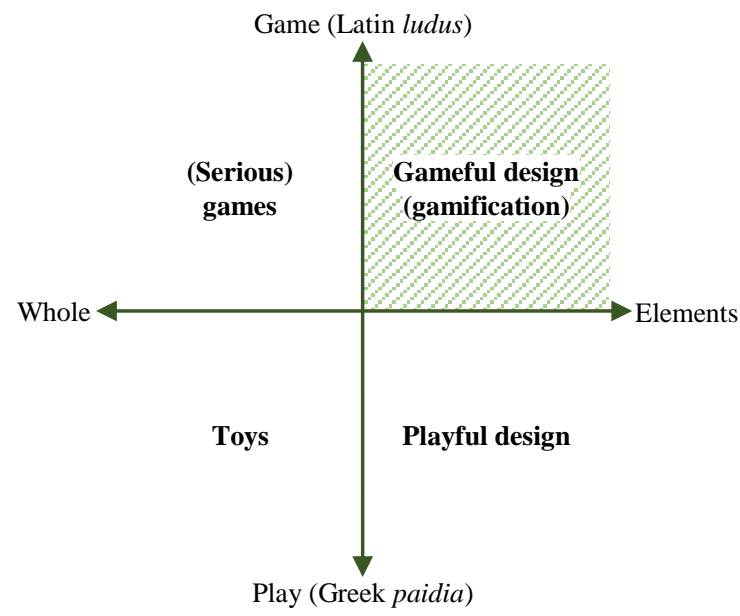

Figure 1. Factors determining customer engagement (based on Deterding et al., 2011)

On the dimension of play (paidia) and game (ludus), Deterding, Dixon, Khaled, and Nacke (2011) distinguish between the concept of gamification (gameful design) and playful design. Whereas on the dimension of elements the distinction is made between the notion of gamification and serious games. In both dimensions, this concept is dissociated from toys (see Figure 1). The place of gamification in a broader context may be discerned in the tendencies of the ludification of culture (see Figure 2).

Although it is a relatively new concept, approaches of many authors trying to present the concept of gamification are very similar. To generalize them, one can state that gamification is the use of mechanics, dynamics and components of games in everyday situations (Zichermann $\&$ Linder, 2010) that are not directly related to games (Bunchball, 2010) and appear in non-game context
(Deterding et al., 2011). Gamification is used with a purpose to create an engaging process that enables to increase consumer perceived product value. In the context of company's activity, gamification serves as a means to get consumers' attention, to advance their involvement and to encourage their participation (Bunchball, 2010).

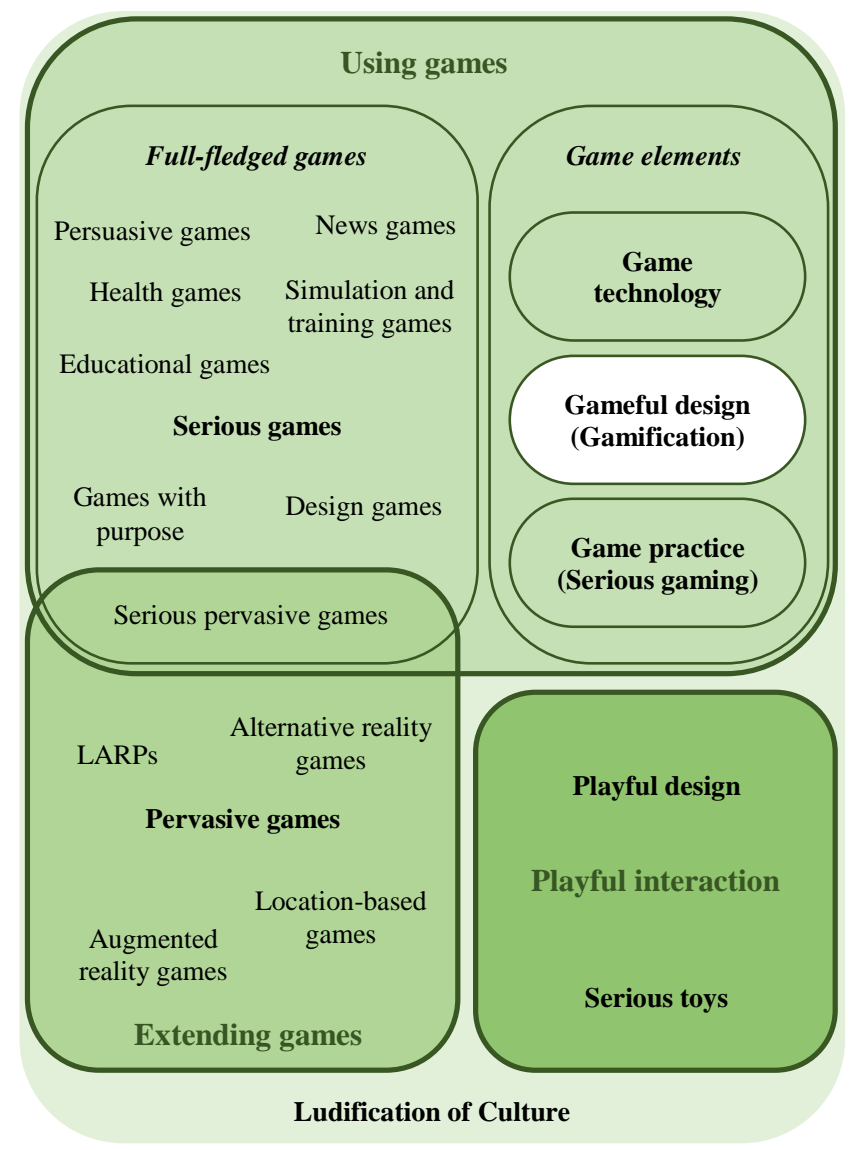

Figure 2. Gamification in the context of the ludification of culture (based on Deterding et al., 2011)

Deterding etal. (2011) have proposed that gamification is related to:

- the use (rather than the extension) of

- design (rather than game creation technology)

- elements (rather than full-fledged games)

- characteristic to games (rather than playfulness) in

- non-game contexts (regardless of specific usage intentions, contexts and means of implementation).

Based on this concept, a company should evaluate all gamification solutions such as design, elements, game characteristics and non-game context.

Factors that stimulate consumer engagement in gamified activities are closely related to motives to engage in games and may be divided into two groups: intrinsic and extrinsic motivating factors. Reiss (2004), Deterding et al. (2011) and McGonigal (2011) agree that intrinsic motivating factors are more important and have a greater influence on consumer behaviour than extrinsic ones. The purpose of gamification conception is to use both intrinsic and extrinsic motivating factors and to increase this way consumer motivation and engagement into gamified activities (von Ahn \& Dabbish, 2008). 


\section{The Key Elements of Gamification}

Game elements allow using gamification in non-game activities and motivate consumers as well as encourage them to perform desired actions. Game elements, supplement non-game activities and help to achieve desired results: achievements, avatars, badges, boss fights, collections, combat, content unlocking, gifting, leaderboards, points, quests, teams, virtual goods. Wu (2011) maintains that game elements may also be an interface between game and player that makes the game or non-game activity more exciting, fun and engaging. The purpose of game elements is to direct consumer behaviour into the desired direction and to satisfy consumer needs. According to Mahadar (2014), every game element carries three types of characteristics: progression, rewarding and recognition. The intensity of these characteristics is different to various game elements.

Typology or classification of game elements area is not adequately addressed in current research. Despite the simplicity of game elements, just several attempts were made to address this issue. Gamification frameworks suggested by practitioners who offer gamification services (such as Chou, 2015; Killian, 2013) are limited to fragmented identification of interrelations of motives to play games and game elements with game elements all treated equally. Therefore, it is the concept of the pyramid of gamification elements suggested by Werbach and Hunter (2012), which offers to separate game elements into three distinct layers, that is referred to most by researchers. The gamification pyramid classifies game elements used for the gamification into game components, game mechanics and game dynamics.

Game dynamics are high-level aspects of the gamified system that determine a further scenario of certain activity that uses gamification (Werbach \& Hunter, 2012). At the highest point of satisfaction, when a certain level or payoff is reached, game dynamics is used to enhance consumers' feelings and emotions. The authors propose the following most important game dynamics:

- Constraints (certain limitations or forced withdrawal).

- Emotions (curiosity, competitiveness, frustration, happiness).

- Narrative (consistent, continuous and ongoing story).

- Progression (consumer's, as player's, growth and development).

- Relationships (friendship created by social interaction, status, altruism).

Game mechanics are means created by game designers to supplement and augment the content of activities where gamification is applied. Game mechanics is often regarded as a particular reward system that uses such elements as points, badges, levels, and virtual goods. According to Werbach and Hunter (2012), game mechanics is a part of gamification use that models and stimulates consumers to investigate and discover their possibilities through feedback. Game mechanics may be very simple and predictable, yet it is important to note that it affects consumers in the desired way, and they are likely to perform actions anticipated by the company. Game mechanics are numerous, and game designers come up with new ones all the time. Gamification researchers and practitioners study the most such game mechanics as (Deterding et al., 2011; Blohm \& Leimester, 2013; Zimmermann \& Cunningham, 2011):

- Exploring (possibilities to freely explore the game / game world).

- Collecting (acquisition of useful or collectable game resources).

- Competition (possibility for a player or a group of players to win while other loose).

- Status acquisition (conditions that have to be met for players to reach a higher level).

- Collaboration (players must act together to achieve a common goal).

- Challenge (quizzes, quests and other tasks that require effort to solve it).

- Development (conditions allowing players to acquire new knowledge or skills).

According to Werbach and Hunter (2012), means used for consumer engagement game context may be called game components. Gamification components make the game exciting and fun to play, and they motivate players to get involved in the activity that uses gamification. Game components act as stimuli and are often directly perceivable from the consumer perspective. Gamification researchers and practitioners study the most such game mechanics as (Seaborn, \& Fels, 2015):

- Points (usually a numerical representation of rewarding the player for activities carried out in a game).

- Badges (the visual representation of player achievements indicating that player reached specific status or level).

- Leaderboards (listing of players based on their performance in the game).

- Levels (a system of advancing in the game by collecting a certain amount of points or carrying out specific actions).

- Rewards (benefits or (game) assets given to a player based on his achievement in the game).

- Feedback (providing the player with information about his performance in the game).

The interaction of various game elements from these different dimensions enables gamification to be implemented in non-game situations. On the other hand, it is important to note that game elements to not make a product or service into a game, it becomes an activity in which a gamification is applied.

\section{Online Consumer Behavior}

For the companies, it is important to understand consumer behavior because marketing planning and strategy should be based on sound knowledge and understanding of target consumers (especially those who constitute a target group) (Urbanskiene, Clothey, \& Jakstys, 2000). As opposed to the traditional environment, the virtual environment has certain unique characteristics (such as interactivity and personalization), which provide better opportunities for companies to develop marketing 
solutions (Gatautis \& Vitkauskaite, 2009). According to Bilgihan, Nusair, Okumus, and Cobanoglu (2015) online "consumers may seek utilitarian benefits, such as ease of use, price and product/service offering comparisons, but they may also consider hedonic benefits, such as visually appealing website designs, which provide enjoyment in the online experience". Kazakeviciute and Banyte (2012) propose that hedonic benefits are increasingly important to consumers.

Laroche (2010) has analysed theoretical studies (from 1998 to 2008) on consumer behavior in virtual environment and classified the models of consumer behavior in the following three groups:

- Models based on environment-response SOR model developed by Mehrabian and Russell (1974) model (where $\mathrm{S}$ is a stimulus, $\mathrm{O}$ is impact/organism, $\mathrm{R}$ is response).

- Models based on Technology Acceptance Model (TAM) (Davis, 1986).

- Model of advances in online information processing.

According to Laroche (2010), scientific literature most often describes consumer behavior based on SOR model that may be complemented with dimensions from TAM model (usefulness and ease of use). Meanwhile, the model of advances in online information processing was relevant at the beginning of internet development.

A number of scientists such as Eroglu, Machleit, and Davis (2001), Sautter, Hyman, and Lukosius (2004), Richard (2005), Oh, Fiorito, Cho, \& Hofacker (2008), J. H. Kim, M. Kim, and Lennon (2009), Mummalaneni (2005), Manganari, Siomkos, \& Vrechopoulos (2009), Bjork (2010) refer to SOR model according to Mehrabian and Russell (1974) when designing online consumer behaviour models.

Elements of the virtual environment or their combinations (stimuli) have an emotional impact on consumers, which in turn prompts positive or negative consumer response (aspiration or avoidance to acquire a product / to perform certain actions) (see Figure 3).
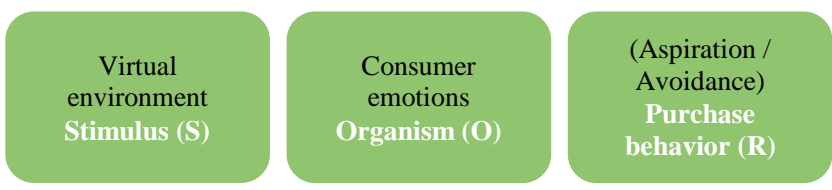

Figure 3. Mehrabian and Russell (1974) stimulus-response (SOR) model, adapted to the virtual environment

In respect to the application of this model in a virtual environment, it should be noted that stimuli are created through elements of virtual environment reaching consumer's consciousness and arousing particular emotions. Positive emotions may induce buying behaviour. All stimuli processed in the consumer's consciousness elicit the response of aspiration or avoidance. Consumers are prompted into aspiration by a pleasant environment and avoidance by unpleasant one (Fiore \& Jin, 2003). Therefore, it is important that companies create an attractive environment that would prompt consumers to buy online.

As Kotler (1973) maintains, a properly designed selling environment has an emotional impact on the consumer and enhances buying possibility. Consequently, it is relevant for companies to create the environment that would have a positive emotional impact on the consumer.

Eroglu et al. (2001) presented a conceptual model of online consumer behaviour. The authors divided stimuli of the virtual environment into two groups: high task-relevant and low task-relevant. According to Eroglu et al. (2001), stimuli of the virtual environment have the emotional and cognitive impact of consumers, which causes a positive or negative response (aspiration or avoidance to purchase a product). The cognitive response is defined as consumer's perception of the environment and its cognitive assessment; it comprises consumer's beliefs, attitudes, knowledge and understanding, previous experience. It is proposed to measure individual emotional impact using the dimensions of PAD model, including dominance (D) dimension (consumer's ability to control the situation in a virtual environment). In the model introduced by Eroglu et al. (2001), involvement and response to the environment that influence the relationship between environmental stimuli and internal status of a person, appear between a stimuli and an individual. A more involved consumer will be more interested in information related to product/service (high task-relevant environment) whereas the one who is less involved will be interested in the low task-relevant environment.

Researchers Sautter et al. (2004) complemented the conceptual online consumer behaviour model of Eroglu et al. (2001, 2003) by introducing the concept of dual environment and additional stimuli that constitute virtual environment.

In the opinion of Sautter et al. (2004), the virtual environment comprises two different environments, i.e., virtual (selling) environment and operator environment. Thus, marketing specialists are recommended not only to pay attention to the components of the virtual environment but also to anticipate and manage the impact of operator environment. Online consumer behaviour models developed by other authors do not contain the concept of the dual environment; therefore, their model is only based on authors' approach.

Authors of this paper support Eroglu et al. (2001) in their approach that virtual environment stimuli have an emotional and cognitive impact on the consumers, which prompts positive or negative response (aspiration or avoidance to acquire a product). It is suggested to measure consumer's emotional impact based on PAD model with an added dominance (D) dimension or using a set of basic emotions proposed. The cognitive impact is defined as easy management, risk awareness, personalization (adaptation to individual needs), and informative aspect.

\section{Gamification Impact on Consumer Behaviour: Perspectives from SOR Model}

As it has already been mentioned, many authors apply SOR model to analyse online consumer behaviour. Consequently, we will further consider the possibilities to use gamification in relation to SOR model.

SOR model involves three components, i.e., stimulus, impact, and response. The gamification model that is most frequently referred to by various authors is based on the gamification pyramid approach proposed by Werbach and 
Hunter (2012) which comprises game components, game mechanics, and game dynamics. These two theoretical approaches are compared in Table 1.

Table 1

Gamification pyramid and SOR model interdependencies (based on Mehrabian \& Russell, 1974, and Werbach \& Hunter, 2012)

\begin{tabular}{l|l|l}
\hline Consumer behaviour & & Gamification concept \\
\hline $\begin{array}{l}\text { Stimuli } \\
\text { Stimuli are created through virtual environment } \\
\text { elements that reach consumer's consciousness and } \\
\text { arouse certain emotions. }\end{array}$ & $\begin{array}{l}\text { Similar to stimuli, } \\
\text { components are meant to } \\
\text { have a certain impact on the } \\
\text { consumer. }\end{array}$ & $\begin{array}{l}\text { Game components } \\
\text { Means to involve consumers that are used in the game context } \\
\text { mame exciting, fun and motivate players to get involved in the } \\
\text { game } \\
\text { activity where gamification is applied. }\end{array}$ \\
\hline $\begin{array}{l}\text { Impact } \\
\text { Consumer state that is evident in the emotional or } \\
\text { cognitive context. }\end{array}$ & $\begin{array}{l}\text { Game mechanics } \\
\text { Game mechanics is a component of gamification which models } \\
\text { and induces consumers to investigate and discover their } \\
\text { possibilities through feedback. }\end{array}$ \\
\hline $\begin{array}{l}\text { Response } \\
\text { Purposeful consumer response. }\end{array}$ & $\begin{array}{l}\text { Game dynamics } \\
\text { Game dynamics are high-level aspects of the gamified system } \\
\text { that determine a further scenario of certain activity that uses } \\
\text { gamification. }\end{array}$ \\
\hline
\end{tabular}

According to various researchers who investigate online consumer behaviour in relation to SOR model, companies use different stimuli to cause a positive impact on the consumer, and they believe that positive impact will encourage the consumer to use company's website or services. In the context of the virtual environment, the stimuli are related to various elements of websites (Gatautis \& Vaiciukynaite 2013) such as website design, website communication elements, website content, and navigation.

In the context of gamification, companies also strive to use various stimuli to achieve desired consumer behaviour, and they use elements that consumers can readily identify, namely, game elements such as avatars, badges, points, levels, virtual gifts. These elements serve as stimuli causing a particular impact on the consumer and leading consumers to a certain state.

In the context of gamification, game dynamics is associated with particular consumer's state. Having reached the state, the consumer is supposed to take further actions, i.e., continue engaging with gamified activities or refuse to participate in gamified activities. As a consequence, it could be stated that game dynamics is related to a state that stimuli should lead to in the context of SOR model.

With reference to Werbach and Hunter (2012), it is possible to claim that game dynamics is not reached solely using game components. Individual game dynamics is achieved due to a combination of game components and game mechanics. Game mechanics determine various combinations of game elements that are chosen while implementing respective game scenarios. Game mechanics is directly related to selected consumer action, which results in a new combination of stimuli (game components) presented to the consumer. Therefore, the conceptual model of the impact of gamification on online consumer behaviour from the perspective of the game pyramid (Figure 4) is complemented with an element of game mechanics.

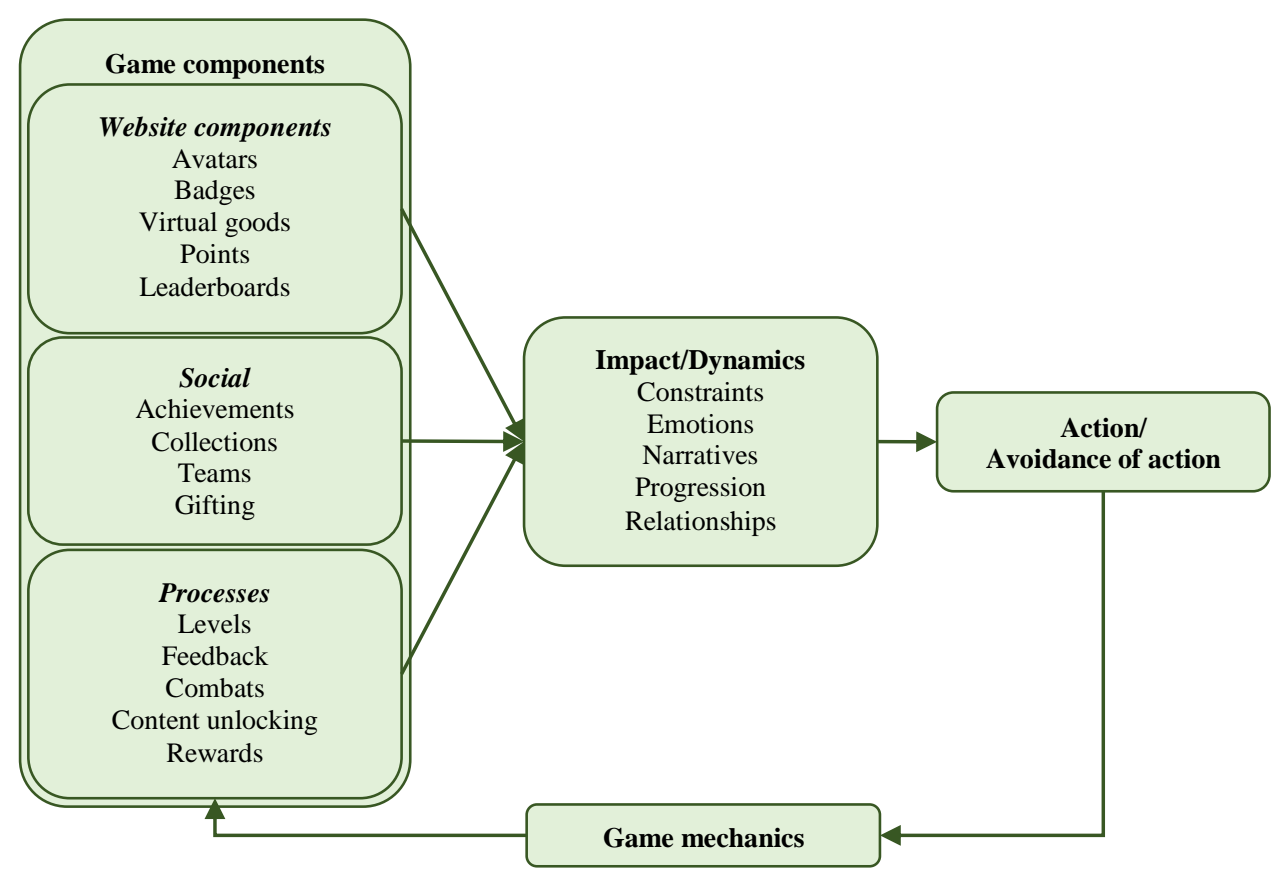

Figure 4. Conceptual model of the impact of gamification on online consumer behaviour 
Considering the number of gamification elements, the three types of game components are outlined:

- Website components that usually identified by the consumer that might be used on websites and they are directly represented to him. Avatars, badges, leaderboards, virtual goods, and points are this kind of game components.

- Process related game components. These components inform the consumer about process involvement perspective (or set of actions needed). They cover such game components as moving from level to level, feedback or other competitors, unlocking new content or new areas.

- A social aspect related game components allow the consumer to interact in the social context or demonstrate their social status. They cover such game components as collaboration in teams, gifting to other players, collections, and achievements.

The proposed types of game components will act as different stimuli for a different type of consumer. From the enterprise point of view, understanding motivation driving the consumer refers to the opportunity to provide appropriate game components (stimuli).

\section{Conclusions}

Despite relation of gamification concept to serious games or playful activities, we define gamification as the use of mechanics, dynamics and components of games in everyday situations that are not directly related to games and appear in non-game context. Gamification is relatively new concept undergoing active discussions aiming to define gamification phenomenon.

There are several attempts at trying to define gamification elements and their application. The most widely discussed and criticized is the gamification pyramid approach proposed by Werbach and Hunter (2012) which proposes to classify game elements into three layers: game components, game mechanics and game dynamics.

From the perspective of online consumer behaviour, various behaviour models might be applied to explain it. However, researchers often refer to SOR model explaining virtual environment as stimuli which leads consumers to a particular state and following with an appropriate action.

As a result of analysis of gamification pyramid approach and SOR model, the interdependencies between these models were identified. Game components typically play stimuli role, and different types of game components can be defined. Game dynamics is described as a particular state of consumer leading to getting further engagement into gamified activities or leaving. According to these action game mechanic interplay with an individual combination game components serving as new stimuli for consumer continuing engagement into gamified enterprise activities

The proposed typology of game components represents consumer interpretation of website elements as well as a different type of motivation to get engaged in games. If it is important to consumers to demonstrate their social status or they are more driven by activities interest enterprises should deploy appropriate game components. The third type of game component - consumers often consider web elements as integral part of websites.

\section{Acknowledgment}

This research (No. VP1-3.1-SMM-07-K-03-083) is funded by the European Social Fund under the Global Grant measure.

\section{References}

Bilgihan, A., Nusair, K., Okumus, F., \& Cobanoglu, C. (2015). Applying flow theory to booking experiences: An integrated model in an online service context. Information \& Management, 52(6), 668-678. doi: 10.1016/j.im.2015.05.005. Available from internet: http://www.sciencedirect.com/science/article/pii/S0378720615 000518

Bjork, P. (2010). Atmospherics on tour operators' websites: Website features that stimulate emotional response. Journal of Vacation Marketing, 16(4), 283-296. doi: 10.1177/1356766710372243. Available from internet: http://jvm.sagepub.com/content/16/4/283.short

Blohm, I., \& Leimeister, J. M. (2013). Gamification. Business \& Information Systems Engineering, 5(4), 275-278. doi: 10.1007/s12599-013-0273-5. Available from internet: http://link.springer.com/article/10.1007/s12599-013-0273-5

Bunchball, (2010). Gamification 101: An Introduction to the Use of Game Dynamics to Influence Behavior. Available from internet: http://www.bunchball.com/sites/default/files/downloads/gamification101.pdf

Caillois, R., \& Barash, M. (2001). Man, play, and games. University of Illinois Press.

Chen, Y., Yan, X., \& Fan, W. (2015). Examining the Effects of Decomposed Perceived Risk on Consumer's Online Shopping Behavior: A Field Study in China. Inzinerine Ekonomika-Engineering Economics, 26(3), 315-326. doi: 10.5755/j01.ee.26.3.8420. Available from internet: http://inzeko.ktu.lt/index.php/EE/article/view/8420

Chou, Y. K. (2015). Actionable Gamification: Beyond Points, Badges, and Leaderboards. Octalysis Media.

Deterding, S., Dixon, D., Khaled, R., \& Nacke, L. (2011). From game design elements to gamefulness: defining gamification. In Proceedings of the 15th International Academic MindTrek Conference: Envisioning Future Media Environments (pp. 9-15). ACM. doi: 10.1145/2181037.2181040. Available from internet: http://dl.acm.org/citation. $\mathrm{cfm} ? \mathrm{id}=2181040$ 
Eroglu, S. A., Machleit, K. A., \& Davis, L. M. (2001). Atmospheric qualities of online retailing: a conceptual model and implications. Journal of Business research, 54(2), 177-184. doi: 10.1016/S0148-2963(99)00087-9. Available from internet: http://www.sciencedirect.com/science/article/pii/S0148296399000879

Eroglu, S. A., Machleit, K. A., \& Davis, L. M. (2003). Empirical testing of a model of online store atmospherics and shopper responses. Psychology \& Marketing, 20(2), 139-150. doi: 10.1002/mar.10064. Available from internet: http://onlinelibrary.wiley.com/doi/10.1002/mar.10064/abstract

Fiore, A. M., \& Jin, H. J. (2003). Influence of image interactivity on approach responses towards an online retailer. Internet Research, 13(1), 38-48. doi: 10.1108/10662240310458369. Available from internet: http://www.emeraldinsight.com/doi/full/10.1108/10662240310458369

Gartner (2014). Gartner's 2014 Hype Cycle for Emerging Technologies Maps the Journey to Digital Business. Available from internet: http://www.gartner.com/newsroom/id/2819918

Gatautis, R., \& Vaiciukynaite, E. (2013). Website Atmosphere: Towards Revisited Taxonomy of Website Elements. Economics and Management, 18(3), 537-544. doi: 10.5755/j01.em.18.3.5285. Available from internet: http://www.sace.ktu.lt/index.php/Ekv/article/view/5285

Gatautis, R., \& Vitkauskaite, E. (2009). eBusiness policy support framework. Inzinerine Ekonomika-Engineering Economics, 65(5), 35-46. Available from internet: http://www.eejournal.ktu.lt/index.php/EE/article/view/11612

Groh, F. (2012). Gamification: State of the Art Definition and Utilization. In Proceedings of the 4th Seminar on Research Trends in Media Informatics Institute of Media Informatics. Available from internet: http://dnb.info/1020022604/34/\#page=39

Hamari, J., \& Koivisto, J. (2015). Why do people use gamification services? International Journal of Information Management, 35(4), 419-431. doi: 10.1016/j.ijinfomgt.2015.04.006. Available from internet: http://www.sciencedirect.com/science/article/pii/S0268401215000420

Hamari, J., \& Lehdonvirta, V. (2010). Game design as marketing: How game mechanics create demand for virtual goods. International Journal of Business Science \& Applied Management, 5(1), 14-29. Available from internet: http://ssrn.com/abstract=1443907

Kazakeviciute, A., \& Banyte, J. (2012). The Relationship of Consumers' Perceived Hedonic Value and Behavior. Inzinerine Ekonomika-Engineering Economics, 23(5), 532-540. doi: 10.5755/j01.ee.23.5.1975. Available from internet: http://www.itc.ktu.lt/index.php/EE/article/view/1975

Killian, E. (2013). Gamification 2.0 - A Concept. Eamonn Killian.

Kim, J. H., Kim, M., \& Lennon, S. J. (2009). Effects of web site atmospherics on consumer responses: music and product presentation. Direct Marketing: An International Journal, 3(1), 4-19. doi: 10.1108/17505930910945705. Available from internet: http://www.emeraldinsight.com/doi/full/10.1108/17505930910945705

Kotler, P. (1973). Atmospherics as a marketing tool. Journal of retailing, 49(4), 48-64.

Laroche, M. (2010). New developments in modeling Internet consumer behavior: Introduction to the special issue. Journal of Business Research, 63(9), 915-918. doi: 10.1016/j.jbusres.2008.12.013. Available from internet: http://www.sciencedirect.com/science/article/pii/S0148296309002094

Mahadar R. (2014). Optimizing gamification design. Cognizant 20-20 Insights. Available from internet: http://www.cognizant.ch/InsightsWhitepapers/Optimizing-Gamification-Design.pdf

Manganari, E. E., Siomkos, G. J., \& Vrechopoulos, A. P. (2009). Store atmosphere in web retailing. European Journal of Marketing, 43(9/10), 1140-1153. doi: 10.1108/03090560910976401. Available from internet: http://www.emeraldinsight.com/doi/full/10.1108/03090560910976401

McGonigal, J. (2011). Reality is Broken: Why Games Make Us Better and How They Can Change the World. Penguin Books, New York, NY.

Mehrabian, A., \& Russell, J. A. (1974). An approach to environmental psychology. The MIT Press.

Meloni, W., \& Gruener, W. (2012). Gamification in 2012: Market Update, Consumer and Enterprise Market Trends. M2 Research. Available from internet: http://wandameloni.snappages.com/gamification-research.htm

Mummalaneni, V. (2005). An empirical investigation of Web site characteristics, consumer emotional states and on-line shopping behaviors. Journal of Business Research, 58(4), 526-532. doi: 10.1016/S0148-2963(03)00143-7. Available from internet: http://www.sciencedirect.com/science/article/pii/S0148296303001437

Oh, J., Fiorito, S. S., Cho, H., \& Hofacker, C. F. (2008). Effects of design factors on store image and expectation of merchandise quality in web-based stores. Journal of Retailing and Consumer Services, 15(4), 237-249. doi: 10.1016/j.jretconser.2007.03.004. Available from internet: http://www.sciencedirect.com/science/article/ pii/S0969698907000240

Reiss, S. (2004). Multifaceted nature of intrinsic motivation: The theory of 16 basic desires. Review of General Psychology, 8(3), 179. doi: 10.1037/1089-2680.8.3.179. Available from internet: http://psycnet.apa.org/journals/ gpr/8/3/179/ 
Rimantas Gatautis, Elena Vitkauskaite, Agne Gadeikiene, Zaneta Piligrimiene. Gamification as a Mean of Driving...

Richard, M. O. (2005). Modeling the impact of internet atmospherics on surfer behavior. Journal of business research, 58(12), 1632-1642. doi: 10.1016/j.jbusres.2004.07.009. Available from internet: http://www.sciencedirect.com/ science/article/pii/S0148296304001948

Robson, K., Plangger, K., Kietzmann, J. H., McCarthy, I., \& Pitt, L. (2015). Is it all a game? Understanding the principles of gamification. Business Horizons, 54(4), 411-420. doi: 10.1016/j.bushor.2015.03.006. Available from internet: http://www.sciencedirect.com/science/article/pii/S000768131500035X

Sautter, P., Hyman, M. R., \& Lukosius, V. (2004). E-Tail Atmospherics: A Critique of the Literature and Model Extension. Journal of Electronic Commerce Research, 5(1), 14-24. Available from internet: http://jecr.ribosome.com.tw/jecr-dev/sites/default/files/05_1_p02_0.pdf

Seaborn, K., \& Fels, D. I. (2015). Gamification in theory and action: A survey. International Journal of Human-Computer Studies, 74, 14-31. doi: 10.1016/j.ijhcs.2014.09.006. Available from internet: http://www.sciencedirect.com/ science/article/pii/S1071581914001256

Sigala, M. (2015). The application and impact of gamification funware on trip planning and experiences: The case of TripAdvisor's funware. Electronic Markets, 1-21. doi: 10.1007/s12525-014-0179-1. Available from internet: http://link.springer.com/article/10.1007/s12525-014-0179-1

Sinanian, M. (2010). The ultimate healthcare reform could be fun and games. Venture Beat.

Urbanskiene, R., Clothey, B., \& Jakstys, J. (2000). Vartotoju elgsena, Kaunas.

Von Ahn, L., \& Dabbish, L. (2008). Designing games with a purpose. Communications of the ACM, 51(8), 58-67. doi: 10.1145/1378704.1378719. Available from internet: http://dl.acm.org/citation.cfm?id=1378719

Werbach, K., \& Hunter D. (2012). For the Win: How game thinking can revolutionize your business. Wharton Digital Press.

Wu, M. (2011). Sustainable gamification: Playing the game for the long haul. In Lithosphere. Available from internet: https://community.lithium.com/t5/Science-of-Social-blog/Sustainable-Gamification-Playing-the-Game-for-the-LongHaul/ba-p/33601

Zichermann, G., \& Cunningham, C. (2011). Gamification by design: Implementing game mechanics in web and mobile apps. O'Reilly Media, Inc.

Zichermann, G., \& Linder J. (2010). Game based marketing: inspire customer loyalty through rewards, challenges and contests. Wiley.

The article has been reviewed.

Received in September 2015; accepted in February, 2016. 